\title{
SOEP
}

SOEPpapers

SOEPpapers
on Multidisciplinary Panel Data Research

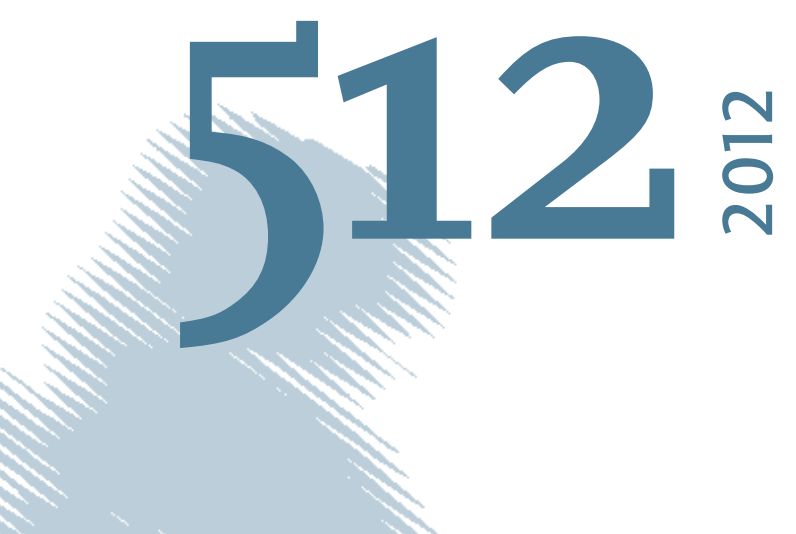

(e)

\section{Offshoring, Wages and Job Security of Temporary Workers}

Holger Görg and Dennis Görlich 


\section{SOEPpapers on Multidisciplinary Panel Data Research}

at DIW Berlin

This series presents research findings based either directly on data from the German SocioEconomic Panel Study (SOEP) or using SOEP data as part of an internationally comparable data set (e.g. CNEF, ECHP, LIS, LWS, CHER/PACO). SOEP is a truly multidisciplinary household panel study covering a wide range of social and behavioral sciences: economics, sociology, psychology, survey methodology, econometrics and applied statistics, educational science, political science, public health, behavioral genetics, demography, geography, and sport science.

The decision to publish a submission in SOEPpapers is made by a board of editors chosen by the DIW Berlin to represent the wide range of disciplines covered by SOEP. There is no external referee process and papers are either accepted or rejected without revision. Papers appear in this series as works in progress and may also appear elsewhere. They often represent preliminary studies and are circulated to encourage discussion. Citation of such a paper should account for its provisional character. A revised version may be requested from the author directly.

Any opinions expressed in this series are those of the author(s) and not those of DIW Berlin. Research disseminated by DIW Berlin may include views on public policy issues, but the institute itself takes no institutional policy positions.

The SOEPpapers are available at

http://www.diw.de/soeppapers

\section{Editors:}

Jürgen Schupp (Sociology, Vice Dean DIW Graduate Center)

Gert G. Wagner (Social Sciences)

Conchita D'Ambrosio (Public Economics)

Denis Gerstorf (Psychology, DIW Research Director)

Elke Holst (Gender Studies, DIW Research Director)

Frauke Kreuter (Survey Methodology, DIW Research Professor)

Martin Kroh (Political Science and Survey Methodology)

Frieder R. Lang (Psychology, DIW Research Professor)

Henning Lohmann (Sociology, DIW Research Professor)

Jörg-Peter Schräpler (Survey Methodology, DIW Research Professor)

Thomas Siedler (Empirical Economics)

C. Katharina Spieß (Empirical Economics and Educational Science)

ISSN: 1864-6689 (online)

German Socio-Economic Panel Study (SOEP)

DIW Berlin

Mohrenstrasse 58

10117 Berlin, Germany

Contact: Uta Rahmann | soeppapers@diw.de 


\title{
Offshoring, Wages and Job Security of Temporary Workers
}

\author{
Holger Görg ${ }^{a, b}$ and Dennis Görlich ${ }^{a}$
}

${ }^{a}$ Kiel Institute for the World Economy, ${ }^{b}$ University of Kiel, CEPR and IZA

\begin{abstract}
We investigate the impact of offshoring on individual level wages and unemployment probabilities and pay particular attention to the question of whether workers on temporary contracts are affected differently than workers on permanent contracts. Data are taken from the German Socio-Economic Panel (SOEP), linked with industry-level data on offshoring of materials and services inputs calculated from the World Input Output Database (WIOD). In manufacturing we find that temporary workers face a significant reduction in wages as materials offshoring increases, while permanent workers' wages are unaffected or even tend to increase. Offshoring of core activities generally also tends to reduce the probability of becoming unemployed, and more so for temporary than for permanent workers. By contrast, offshoring of services inputs does not have any statistically significant effects on either wages or employment probabilities in manufacturing. In the service industries, workers are affected in terms of employment probabilities from offshoring of services inputs only, although, in contrast to manufacturing industries, there are no statistically significant effects on individual wages from any type of offshoring.
\end{abstract}

Acknowledgements: The authors are grateful to Paul Osterman, Bernhard Boockmann, and conference participants at the ILRR Conference on job quality at Cornell University and the Aarhus-Kiel Workshop 2011 for very helpful comments on an earlier draft. Thanks are also due to Tillmann Schwörer for help with the WIOD data. Fares Al-Hussami provided excellent research assistance. The authors gratefully acknowledge financial support through the European Commission as part of the 7th Framework Programme, Grant Agreement No. 244552 (SERVICEGAP). 


\section{Introduction}

An important facet of today's world economy is that trade is no longer mostly in final goods. Instead, the recent wave of globalization is characterized by the strong emergence of vertical specialization and offshoring of production (see Yi, 2003). The labour market consequences of this offshoring of production are debated in the media as well as among policy makers and academic economists.

At least since Feenstra and Hanson (1999) trade economists have concerned themselves with investigating the impact of offshoring on labour markets. While Feenstra and Hanson (1999) and many papers since investigate this issue using industry or country level data, recent research tends to use individual level data in order to examine whether offshoring has any impact on an individual's job security or wage. Using micro data has the advantage that it allows to focus on the level of the individual where one can control for observable and unobservable characteristics that may play a role for job turnover or wages, but that cannot be controlled for in firm or industry data (e.g., age, tenure or marital status of a worker). Also, it provides information on the various aspects of skills of an individual, which can be exploited in the estimations.

A number of recent studies have taken this approach. Baumgarten et al. (2010), Ebenstein et al. (2010), Liu and Trefler (2008) and Görg and Geishecker (2008, 2012) use individual level data for the US, Germany and the UK, respectively, to study the impact of offshoring on individual wages. Liu and Trefler (2008), Geishecker (2009), Bachmann and Braun (2011) and Egger et al. (2007) also use individual level data for the US, Germany and Austria, respectively, to investigate whether offshoring has any implications for job security, measured in terms of whether an individual switches jobs or moves into unemployment. Overall, it seems from this literature that, in general, outsourcing may have some effects on employment in line with expectations, where low skilled workers may be more likely to lose 
and high skilled workers more likely to benefit in terms of job security and wages. However, any effects of outsourcing on employment are likely to be very small in terms of economic significance.

What has, to the best of our knowledge, been neglected in this literature thus far is the question as to how workers with different types of contracts fare in this wave of offshoring. This is the focus of this paper, where we particularly consider whether workers on temporary contracts experience different labour market effects of offshoring than their peers on permanent contracts. This is an important issue, given the recent increase in temporary work arrangements, particularly in some European countries. Germany, the country studied in this paper, has recently witnessed a strong increase in temporary work arrangements, especially among young workers. Looking at total German employment, the share of temporary contracts increased slightly from 13\% in 1999 to $14.5 \%$ in 2009 (according to Eurostat statistics). This share is comparable to most other European countries. ${ }^{1}$ However, among younger workers (up to 24 years old), the share of workers with temporary contracts in 2009 is higher in Germany than in the rest of Europe (57\%; up from 53\% in 1999).

While, in principle, all workers in an industry are equally likely to be affected by the pressures on labour brought about by offshoring, there are several reasons to believe that workers on temporary contracts are affected differently than workers on permanent contracts. Workers on temporary contracts are the least protected workers on the labor markets. This leads Booth et al. (2002a) to characterize temporary labour under fixed-term contracts as "a buffer stock that allows firms to adjust to changes in the business environment due to seasonal or other transitory causes” (p. F182). Accordingly, if firms and industries adjust to offshoring, this may lead to a stronger adjustment among temporary workers, and they might

\footnotetext{
${ }^{1}$ An exception is Spain, which exhibits an exceptionally high share of temporary contracts with figures ranging from $25 \%$ to $34 \%$.
} 
have a stronger propensity to lose their job due to international competition. Moreover, due to their generally weaker bargaining position they might also suffer from stronger wage reductions, in case employers adjust to globalization pressure at the intensive margin.

We address the question of whether employees on temporary contracts are differently affected by offshoring by looking at individual wages and the risk of becoming unemployed. Data are taken from the German Socio-Economic Panel (SOEP), an annual, representative, and widely used individual level panel data set for Germany. In order to integrate offshoring into the data, we link the SOEP with industry-level data on imports of materials and services inputs calculated from a newly available database, the World Input Output Database (WIOD). Since the SOEP includes information on contract type of workers, we interact offshoring intensities with contract type and can thus infer the potentially differential impact of offshoring on permanent and temporary workers.

Our empirical analysis shows that workers in manufacturing and services are most strongly affected by offshoring of, what one may call their industries' “core inputs”. In manufacturing we find that temporary workers face a significant reduction in wages as materials offshoring increases, while permanent workers' wages are unaffected or even tend to increase. Offshoring of core activities generally also tends to reduce the probability of becoming unemployed, and more so for temporary than for permanent workers. By contrast, offshoring of services inputs does not have any statistically significant effects on either wages or employment probabilities in manufacturing. A somewhat similar pattern can be observed for workers in the service industries. They are affected in terms of employment probabilities from offshoring of core activities, i.e., services inputs, although, in contrast to manufacturing industries, there are no statistically significant effects on individual wages from any type of offshoring.

The remainder of the paper is structured as follows. The next section presents some stylized facts on the use of temporary contracts in European countries, while Section 3 gives 
an overview of the development of offshoring. Section 4 then presents our methodological approach and introduces the data set. In Section 5 we discuss our empirical results, looking first at workers in manufacturing industries and then in services industries. We highlight similarities and differences between the two sectors of economic activity. Section 6 discusses the main results and concludes.

\section{Stylized facts on temporary work arrangements}

The use of temporary work arrangements, defined more specifically as holding a temporary, fixed-term contract, has been on the rise in some developed countries. ${ }^{2}$ Table 1 summarizes the incidence of temporary contracts for different age groups in several European countries and the US. Focussing on the total workforce first (panel A), it shows that the use of temporary contracts varies widely among the countries. While temporary contracts are not widely used in the UK and US, they are extremely common in Spain where between onefourth and one-third of the workforce holds a temporary contract. Germany, which is the focus of this study, lies in between these extremes, with rates similar to those in France and Italy.

Temporary contracts are particularly common among young workers. According to the OECD (2008), temporary employment has become a major mode of entry to the labour market for young workers in many European countries. Panel B in table 1 shows the incidence among workers aged between 15 and 24. In the European Union, about 40 per cent of young workers hold a temporary contract. In Germany, the share of temporary workers among the young has increased from 53 to 57 per cent between 1999 and 2009 and has

\footnotetext{
${ }^{2}$ Temporary work is defined according to Eurostat in this section: Employees with a limited duration job/contract are employees whose main job will terminate either after a period fixed in advance, or after a period not known in advance, but nevertheless defined by objective criteria, such as the completion of an assignment or the period of absence of an employee temporarily replaced. Seasonal work, employment via a temporary work agency and persons with specific training contracts are also included here.
} 
become even higher than in Spain. The increase has been much stronger in Italy though, where the incidence increased from 26 to 44 per cent over the same period. In Spain, the share of temporary workers has decreased strongly from 70 to 56 per cent. The incidence of temporary contracts among youth is, again, low in the US and the UK.

\section{[Table 1 here]}

Temporary work is also relatively common among workers with low educational attainment (see also Bentolila \& Dolado, 1994). Table 2 (panel A) shows that, for all age groups, one-third of workers with primary education hold a temporary contract in 2009 (up from one-fourth in 1999). Among workers with secondary or tertiary education, only 10 or 8 per cent hold a temporary contract, respectively. The sample of young workers (panel B) shows that about 80 per cent of youth with primary education held a temporary contract in 1999. This share has declined slightly over time (to 77 per cent in 2009). In contrast, the incidence among youth with secondary or tertiary education has increased strongly, from 32 to 40 per cent and from 27 to 35 per cent, respectively.

\section{[Table 2 here]}

The incidence of temporary contracts is related to the strictness of employment protection legislation (EPL) for permanent contracts. As Booth et al. (2002a) argue, temporary contracts are frequently used as a means of providing employment flexibility in countries where employment protection is high for permanent contracts. Furthermore, the gap between EPL for temporary and permanent contracts is also relevant for explaining the prevalence of temporary jobs (e.g. Bentolila et al., 2010). Strict EPL for permanent contracts, but low EPL for temporary contracts, creates a wedge between firing costs for permanent and temporary workers so that firms may be hesitant to transform temporary contracts into permanent ones (Blanchard \& Landier, 2002). This will create dual labour markets, with a relatively weakly protected temporary workforce (which is predominantly young and low educated) and a well-protected permanent workforce. In a recession with many jobs being 
shed, this can result in high levels of unemployment among groups with a high prevalence of temporary contracts (cf. Blanchard and Landier, 2002; Cahuc and Postel-Vinay, 2002; Boeri and Garibaldi, 2007). ${ }^{3}$

Analyzing firm-level determinants of temporary work in the US, Houseman (2001) finds that employers hire temporary workers (specifically, on fixed-term contracts) due to seasonal needs, special projects, or the special expertise possessed by the temporary worker. Other reasons include the desire to screen an employee before offering a permanent contract, the temporary replacement of a permanent worker on sick leave or family leave, or unexpected increases in business. Note, however, that employers with these objectives are more likely to hire agency temporaries, on-call workers or part-time workers. Houseman also reports that the usage of temporary work increases with establishment size and that it is low in manufacturing relative to other industries. Gramm and Schnell (2001) suggest that also a business strategy, which emphasizes low-cost production, is associated with a strong prevalence of temporary work.

Temporary work may have certain benefits because these types of contracts offer more flexibility to employers. In fact, EPL on temporary contracts was weakened in order to decrease employers' hiring costs and to decrease unemployment. Yet, numerous authors have shown that temporary contracts also bring a number of undesirable labour market outcomes with them. Booth et al (2002b) show that temporary workers earn lower wages, are less satisfied with their job, and receive less on-the-job-training than permanent workers. Moreover, they are provided with fewer benefits, such as paid vacation, sick leave, pensions, or health insurance, and they do not take part in profit sharing (Houseman, 2001). Temporary

\footnotetext{
${ }^{3}$ However, lower EPL for temporary jobs should also increase overall employment as employers may be more willing to create jobs given the lower cost of eliminating jobs.
} 
workers also more often report inflexible work schedules and monotonous job tasks (OECD, 2002).

The lowering of EPL for temporary jobs relative to EPL for permanent jobs has also increased labour market volatility (Costain et al., 2010). Job turnover in low-productivity entry-level jobs increased and fewer permanent jobs are offered. This leads to a decline in overall productivity and welfare (Blanchard \& Landier, 2002; OECD, 2004). There is also evidence for a number of European countries that temporary work substitutes permanent work and that the increasing wedge between temporary and permanent EPL did not increase total employment, as it was intended initially (Kahn, 2010).

Nevertheless, there also appear to be a few desirable outcomes: the use of temporary contracts by employers enhances employment stability for regular core employees who hold permanent contracts (Gramm \& Schnell, 2001). Moreover, low-paid temporary jobs are found to be serving as stepping stones for better paying, more stable jobs for a majority of youth across OECD countries, while only a minority remains in low-paid, temporary jobs (OECD, 2008). In fact, between one-third and two-thirds of temporary workers manage to obtain a permanent job within two years, but transition probabilities are smaller for lower educated workers. Up to one-fourth of temporary workers become unemployed, but a larger number remains in temporary jobs (OECD, 2002).

\section{$3 \quad$ Measuring offshoring}

The next step in the analysis is to come up with measures of offshoring. Empirical work in international trade generally gauges the importance of offshoring by looking at imports of intermediate goods. Following Feenstra and Hanson (1999), many studies use input-output tables to estimate the importance of intermediate goods trade for certain industries. We follow this approach here. Specifically, we use the World Input Output Database (WIOD) to calculate offshoring measures for manufacturing and services industries 
in Germany. ${ }^{4}$ The WIOD has a number of advantages over commonly used measures of offshoring, which are generally based on national input output tables. ${ }^{5}$ The most important advantages are that WIOD contains a breakdown of input-output relations by supplier country, and, hence, allows identifying where the inputs of a specific industry are sourced. Also, the supply and use tables underlying the world input-output table are more frequently available than input-output tables from EUROSTAT or the OECD. Hence, measurement bias from the imputation of missing data is reduced considerably.

As in Schwörer (2012) we use the WIOD data to calculate measures of material and services outsourcing relative to industry output. Hence, we calculate a measure of material offshoring, which is defined as the amount of imported material inputs used by the domestic two-digit industry $j$. This is scaled by total output of the domestic industry $j$. Similarly, we calculate a measure of offshoring of services inputs relative to total output for each two digit industry. ${ }^{6}$

Figure 1 shows the development of materials (upper panel) and services offshoring (lower panel) across German manufacturing industries between 1999 and 2009. It is clear that there are differences in the level of imports of material inputs, with the food/beverage industry showing a ratio of material imports to output of around 5 percent, while industries such as transport equipment or basic and fabricated metals are over 20 percent. However, in most industries there is also a clear and upward trend over time, with little fluctuations. This pattern is similar for imports of services inputs in manufacturing industries, although the level is here much lower than for material inputs.

\footnotetext{
${ }^{4}$ The WIOD is available at http://www.wiod.org/database/index.htm. See Timmer (2012) for a detailed description of the construction of the world input-output tables.

${ }^{5}$ These advantages are discussed in detail in Timmer (2012) and Schwörer (2012).

${ }^{6}$ The exact definitions of our offshoring measures are described in the Appendix A1.
} 
Figure 2 presents similar data for offshoring of materials (upper panel) and services inputs (lower panel) in services industries.

[Figures 1 and 2 here]

\section{$4 \quad$ Methodology and data}

The aim of the analysis is to investigate the effect of offshoring on individual wages and employment probabilities and to see whether temporary work arrangements affect these outcomes. Such labour market effects may strongly depend on individual level characteristics, such as education, age, tenure etc. In order to be able to abstract from such confounding effects we therefore turn to an econometric analysis where we use individual level data combined with the industry level measures of offshoring. We look at two possible labour market outcomes, namely, individuals’ wages and individuals’ probability of moving into unemployment.

The analysis is based on individual level data from the German Social Economic Panel (SOEP). ${ }^{7} \quad$ Our sample includes male full-time employees of prime age (i.e., aged 1864) who are employed in manufacturing (NACE 15-36) or services industries (NACE 40-74). The SOEP provides rich information on individual characteristics, including the industry in which an individual works, and the type of contract (permanent or temporary). It is important to point out that, in contrast to the Eurostat measure used above, temporary contracts only include fixed-term contracts here. Work for temp agencies is not part of the measure. Moreover, we exclude apprentices and trainees from our estimation sample as they have a rather specific and special status on the German labour market.

\footnotetext{
${ }^{7}$ See Wagner et al. (2007) for a good description of the SOEP data base.
} 
We exploit the individual level characteristics available in the SOEP in this analysis. Using the industry identifier we combine the individual level data with the industry level data on offshoring described in Section 3. The analysis spans the period 1999 to 2009.

The first part of the analysis looks at wages. To investigate the relationship between offshoring and individuals' wages we estimate variants of the following Mincerian wage regression: ${ }^{8}$

(1) $\ln W A G E_{i j t}=\alpha+\beta X_{i t}+\gamma_{1} O F F_{j t}+\gamma_{2} T E M P_{i t}+\gamma_{3}\left(O F F_{j t} * T E M P_{i t}\right)+R n D_{j}+d_{j}+d_{t}+d_{i}+v_{i t}$

where $W A G E$ is the real monthly gross wage for individual $i$ in industry $j$ in year $t$. As explanatory variables we include a vector $X$ of individual specific characteristics (including marital status, tenure, work experience, education, size and ownership of the firm where the individual works, and a dummy for individuals living in East Germany). ${ }^{9}$ Dummies for industry $j$, time $t$ and individual $i$ control for unobserved effects at these levels. We also include a measure of industry-level R\&D (relative to the output of industry $j$ ) in order to control for technical change that is specific to an industry. Industry-level R\&D data are taken from the ANBERD database provided by the OECD. Given that we combine individual and industry level data for the estimation of equation (1), we cluster the error term $v_{i t}$ by two digit industry.

The main variables of interest are the vector $O F F$ which includes the two offshoring measures (materials or services) as described in Section 3 and TEMP, which is an indicator variable equal to one if the individual holds a temporary contract and zero if the contract is permanent. The interaction term $O F F * T E M P$ captures the differential effect (if any) of offshoring on wages for workers with temporary contracts.

An important assumption implicit in our estimation is that of exogeneity of regressors. This may be questionable in particular with respect to the offshoring variables. These may be

\footnotetext{
8 This approach is similar to Geishecker and Görg $(2008,2011)$ and Liu and Trefler (2008). However, these papers do not allow for differential effects depending on the type of employment contract.

${ }^{9}$ A definition of the explanatory variables is in Appendix A2.
} 
endogenous due to reverse causality - industries with unskilled intensive production (and low wages for unskilled workers) may also be those that are more likely to offshore. However, given that there is substantial heterogeneity in individual wages it is unlikely that reverse causality is an issue. Also, we control for industry-level fixed effects, which would control for time invariant characteristics, such as production technology at the industry level. Another potential source of correlation between the offshoring variable and the error term is measurement error. However, such concerns are mitigated by the use of the WIOD database which arguably provides far more reliable measures of offshoring than those based on national input-output tables generally used in the literature. The summary statistics presented in Figures 1 and 2 also show that there are no sudden unexpected movements in the data which may suggest measurement error.

Still, in order to tackle concerns related to these points, we also conduct an instrumental variables approach and test explicitly the assumption of exogeneity of the offshoring variables using a C-test (Baum et al., 2003). We use information on world material offshoring as instruments. These are calculated using the output-weighted average of offshoring in all 40 countries covered by the WIOD data. Arguably, offshoring activities of the same industry in different countries are driven by the same global factors. We thus expect a close correlation between world offshoring activities and German offshoring within any given manufacturing industry. At the same time, world-wide offshoring activities are unlikely to have a direct impact on wages at the worker level in Germany. Hence, world offshoring activities should be valid as well as relevant instruments. This latter also shown formally by means of a first stage F-test and a test of underidentification provided in Appendix A3. The C-test indicates that we cannot reject exogeneity of services and materials offshoring. Accordingly, the efficiency loss associated with instrumenting for offshoring cannot be justified and the estimation of equation (1) without instrumenting can be considered to provide consistent estimates of the true parameters. 
The second part of the analysis looks at employment probabilities. To investigate the link between an individual's probability of losing her job and offshoring we estimate the probability of job loss conditional on individual and industry characteristics:

(2) $\operatorname{Pr}(j o b \text { loss })_{i j t}=\alpha X_{i t}+\lambda_{1} O F F_{j t}+\lambda_{2} T E M P_{i t}+\lambda_{3}\left(O F F_{j t} * T E M P_{i t}\right)+R n D_{j}+d_{j}+d_{t}+d_{i}+e_{i t}$

where job loss is defined as a dummy variable equal to one if the individual $i$ moves from full-time employment in period $t$-1 into unemployment in period $t$ and zero otherwise. The explanatory variables are identical to those in equation (1). Given the binary nature of the dependent variable the model is estimated using probit techniques. The error term allows for clustering at the two digit industry level. ${ }^{10}$

\section{$5 \quad$ Results}

This section discusses the results of our econometric estimations. Before we look at the impact of offshoring, we investigate the determinants of holding a temporary contract. We regress $T E M P$ on a number of individual specific variables. Also, we include industry level offshoring and R\&D. Column (1) is based on total offshoring, while columns (2) and (3) are based on offshoring measures calculated separately for offshoring to non-OECD and OECD countries, respectively.

The results from a probit estimation are reported in Table 3 for individuals in manufacturing and services industries. Many individual characteristics can explain the probability of holding a temporary contract. We find that workers are more likely to hold such a contract if they have less than secondary education, low tenure, low work experience, or if they work in a large firm. By contrast, offshoring and R\&D at the industry level are not significantly correlated with the incidence of a temporary contract.

[Table 3 here]

\footnotetext{
10 This approach is similar to Geishecker (2008) and Bachmann and Braun (2011) who, however, only consider the period 1991 to 2000. Also, they do not distinguish temporary and permanent work arrangements.
} 
We now investigate the impact of offshoring on wages and the probability to become unemployed separately for manufacturing and service industries. We split by manufacturing and service industries as we would expect, given the different nature of manufacturing and services activities, that we find different effects of materials and services offshoring in these two industries. After all, materials are core inputs in manufacturing industries, and services are core inputs in service industries.

The specifications are estimated with offshoring of materials and services. Additionally, we distinguish between offshoring to low-wage (non-OECD) and high-wage (OECD) countries. We begin by summarizing the results for manufacturing industries, followed by a summary for service industries. We present in the tables only marginal effects for our offshoring variables, distinguishing effects for individuals with permanent and temporary contracts. The full regression results, including all control variables, are relegated to Appendix A4.

\subsection{Effects on wages in the manufacturing sector}

Table 4 shows the marginal effects obtained from fixed-effects regressions on individual real log hourly wages of workers in the manufacturing sector. In specification 1 , we include the measures for materials and services offshoring, which we introduced in Section 3 and interact these with a dummy for holding a temporary contract. In specifications 2 and 3, we additionally distinguish by offshoring to non-OECD and OECD countries, respectively.

In terms of the control variables (see Appendix Table A1) we find that all coefficients of all covariates have the expected signs, and their order of magnitude is comparable to previous studies of wages. A number of coefficients is statistically insignificant, which is not surprising as the equation includes individual fixed effects and, hence, only exploits the within variation in the data. The adjusted R2 signals a good fit of the model. 
The marginal effects displayed in Table 4, column (1) show that materials offshoring negatively affects wages of workers with temporary contracts, while there is no statistically significant effect on wages of permanent workers. The marginal effects in fact, help to quantify the impact: a 1-percentage point increase in materials offshoring reduces the wages of temporary workers by 0.7 percent. With an average increase of materials offshoring of 3 percentage points during the period of analysis, this boils down to a real wage loss of 2.1 percent over a 10-year period.

[Table 4 here]

When we distinguish offshoring to low- and high-wage countries (non-OECD and OECD countries, respectively) in columns (2) and (3), we find that the negative wage effect of materials offshoring on temporary workers remains, and that the marginal effect is almost twice as large for offshoring to low-wage countries as for offshoring to OECD countries. On average, materials offshoring to low-wage countries has increased by 2.4 percentage points over the period of analysis, implying that temporary workers faced an offshoring-induced real wage reduction of 4.1 percent over a 10-year period. Over the same time, offshoring to OECD countries increased by 0.5 percentage points, yielding a wage reduction by 0.5 percent. Hence, offshoring to non-OECD countries has had much stronger economic implications for wages of workers on temporary contracts than offshoring to OECD countries.

Moreover, we find that materials offshoring to low-wage countries has a positive impact for workers with permanent contracts, although the estimate is only statistically significant at the 10 percent level. The coefficient estimate is also positive for offshoring to OECD countries, though it is statistically insignificant. In the theoretical framework of Grossman and Rossi-Hansberg (2008) this suggests that offshoring, in particular to low-wage countries, raises the productivity of workers on permanent contracts.

The impact of services offshoring is in all cases statistically insignificant. 


\subsection{Effects on probability of moving into unemployment, manufacturing sector}

We now look at the impact of offshoring on the probability of becoming unemployed in manufacturing industries. Marginal effects of offshoring for different contract types, based on probit estimations of equation (2) are shown in Table $5 .{ }^{11}$ We find that materials offshoring reduces the probability of becoming unemployed. This is the case for both offshoring to OECD and non-OECD countries for workers on permanent contracts. This result in conjunction with the positive wage effects of offshoring strongly suggests that there are positive productivity effects of offshoring, but only for workers holding permanent contracts. These workers reap the benefits of offshoring in terms of both higher wages and more secure employment prospects.

\section{[Table 5 here]}

For workers on temporary contracts we find a statistically significant negative effect of offshoring only for offshoring to OECD countries. This effect is statistically insignificant (thought still negative) when offshoring goes to low-wage countries. Thus, offshoring to low-wage countries does not benefit temporary workers; it leaves their employment relationship unaffected and leads to reduced wages. Offshoring to high-wage countries, however, benefits temporary workers in terms of lower job loss probabilities. However, this increased job stability comes at a price, as temporary workers experience wage losses due to this type of offshoring.

\footnotetext{
${ }^{11}$ The probits are reported in Appendix A4, Table A2. The estimated coefficients of the control variables all have the expected signs: education, tenure, experience, and firm size reduce the likelihood of becoming unemployed, whereas living in the Eastern part of Germany is associated with a higher unemployment risk. Note that the probit regressions are estimated for the pooled cross-section and do not contain individual fixed effects. A fixed-effects logit regression would exclude all individuals who have not switched between permanent and temporary contracts, leaving us with a rather small sample for estimation. Moreover, the control variables only change marginally in most cases so that we run into serious identification problems with a fixedeffects approach.
} 
Services offshoring again does not yield any statistically significant results, with the exception of a negative effect for temporary workers in column (1). However, this coefficient estimate is not robust to distinguishing offshoring by destination country.

\subsection{Effects on wages in the service sector}

Table 6 shows the results for wage regressions for the services sector. Again, the estimated coefficients of our control set have the expected signs (Appendix A4). However, we find that there are no statistically significant wage effects of offshoring, neither for workers on permanent nor for workers on temporary contracts. This is true for both materials and services offshoring. Also, distinguishing offshoring from low and high wage countries does not change this result.

[Table 6 here]

\subsection{Effects on probability of moving into unemployment in the service sector}

The marginal effects from the probit regressions of moving into unemployment for the services sector are shown in Table 7 . The impact of services offshoring on the probability of becoming unemployed is statistically insignificant for workers of both contract types when we consider total offshoring. However, distinguishing between offshoring to low- and highwage countries reveals some interesting patterns. The probability of moving into unemployment tends to decrease when services inputs are imported from high-wage countries. By contrast, the coefficients are positive, though statistically insignificant for services offshoring to low-wage countries. This may suggest that services offshoring to highwage economies leads to productivity improvements which imply higher job security but do not lead to higher wages for workers. These effects are stronger for temporary than for permanent workers. Offshoring to low-wage countries, however, does not have any positive effects on domestic workers. 
Looking at the effect of materials offshoring, we find that it does not have a statistically significant impact on the probability of moving into unemployment, irrespective of the worker's contract type and offshoring destination.

[Table 7 here]

\section{Discussion and conclusions}

Our findings suggest that workers in manufacturing and services are most strongly affected by offshoring of their industries' “core inputs”. These effects are generally stronger for workers on temporary contracts than for permanent workers. In manufacturing industries, material inputs can be regarded as "core inputs”. We find that temporary workers face a significant reduction in wages as materials offshoring increases, while permanent workers' wages are unaffected or even tend to increase. Offshoring of core activities generally also tends to reduce the probability of becoming unemployed for all types of workers, and this positive effect appears to be larger for temporary than for permanent workers. By contrast, offshoring of non-core activities (i.e., services inputs in the manufacturing sector) do not have any statistically significant effects on either wages or employment probabilities.

A somewhat similar pattern can be observed for workers in the service industries. They are affected in terms of employment probabilities from offshoring of core activities (i.e., services inputs), although there are no statistically significant wage effects from any type of offshoring.

The effects of offshoring on reducing the risk of becoming unemployed may suggest that offshoring leads to productivity improvements (Grossman and Rossi-Hansberg, 2008) which in turn lead to more stable employment relationships for workers with both temporary and permanent contracts. However, this does not necessarily imply higher wages. In fact, in manufacturing industries temporary workers seem to face a tradeoff. A reduction in wages 
due to offshoring is matched by a reduction in unemployment risk. This does not appear to be the case in services industries, however.

Overall, given the strong trend in Germany towards dual labour markets with permanent and temporary employees, and increasing levels of globalization through offshoring, the separate identification of the effects of offshoring for the two types of workers is important. Our findings provide some evidence for the policy debate on whether globalization and employment insecurity are linked (Rodrik, 1997, Scheve and Slaughter, 2004) by investigating whether the nature of employment contracts matters. While a full answer to this issue would clearly need further research, we take our paper as providing a first step in this direction. 


\section{References}

Amiti, M. and S.J. Wei, 2005, Fear of service outsourcing: is it justified?, Economic Policy, 20, 308-347.

Bachmann, R. and S. Braun, 2011, The Impact of International Outsourcing on Labour Market Dynamics in Germany, Scottish Journal of Political Economy, 58, 1-28.

Baum, C.F., M.E. Schaffer, and S. Stillman, 2003, Instrumental Variables and GMM: Estimation and Testing, Stata Journal, 3, 1-31.

Baumgarten, D., I. Geishecker and H. Görg, 2010, Offshoring, tasks, and the skill-wage patter, CEPR Discussion Paper 7756.

Bentolila, S., P. Cahuc, J. Dolado and T. Le Barbanchon, 2010, Two-Tier Labor Markets in the Great Recession: France vs. Spain, IZA Discussion Papers 5340, Institute for the Study of Labor (IZA).

Bentolila, S., J. Dolado, W. Franz and C. Pissarides, 1994, Labour Flexibility and Wages: Lessons from Spain, Economic Policy, 9 (18), 53-99.

Blanchard, O. and A. Landier, 2002, The Perverse Effects of Partial Labour Market reform: Fixed-Term Contracts in France, Economic Journal, 112, F214-F244.

Boeri, T. and Garibaldi P., 2007, Two Tier Reforms of Employment Protection: a Honeymoon Effect?, Economic Journal, 117, 357-385.

Booth, A.L., J.J. Dolado and J. Frank, 2002a, Symposium on Temporary Work: Introduction, Economic Journal, 112(480), F181-F188.

Booth, A.L., M. Francesconi and J. Frank, 2002b, Temporary Jobs: Stepping Stones or Dead Ends?, Economic Journal, 112(480), F189-F213.

Cahuc, P. and F. Postel-Vinay, 2002, Temporary Jobs, Employment Protection and Labor Market Performance, Labour Economics, 9, 63-91.

Costain, J., F. Jimeno and C. Thomas, 2010, Employment fluctuations in a dual labor market, Banco de España Working Papers 1013, Banco de España.

Dolado, J.J., C. García-Serrano and J.F. Jimeno, 2002, Drawing lessons from the boom of temporary jobs in Spain, Economic Journal, 112, F270-F295

Feenstra, R.C. and G.H. Hanson, 1999, The Impact of Outsourcing and High-Technology Capital on Wages: Estimates for the United States, 1979-1990, Quarterly Journal of Economics, 114, 907-941.

Geishecker, I., 2008, The Impact of International Outsourcing on Individual Employment Security: A Micro-Level Analysis, Labour Economics, 15, 291-314 
Geishecker, I. and H. Görg, 2008, Winners and losers: A micro-level analysis of international outsourcing and wages, Canadian Journal of Economics, 41, 243-270

Geishecker, I. and H. Görg, 2012, Services offshoring and wages: Evidence from micro data, Oxford Economic Papers, forthcoming.

Gramm, L. and F. Schnell, 2001, The Use of flexible staffing arrangements in core production jobs, Industrial and Labor Relations Review, 54(2), 245-258.

Grossman, G. and E. Rossi-Hansberg, 2008, Trading tasks: A simple theory of offshoring, American Economic Review, 98, 1978-1997.

Hagen, T., 2002, Do Temporary Workers Receive Risk Premiums? Assessing the Wage Effects of Fixed-term Contracts in West Germany by a Matching Estimator Compared with Parametric Approaches, Labour Economics, 16(4), 667-705.

Houseman, N., 2001, Why Employers Use Flexible Staffing Arrangements: Evidence from an Establishment Survey, Industrial and Labor Relations Review, 55(1), 149-170.

Kahn, M., 2010, Employment protection reforms, employment and the incidence of temporary jobs in Europe: 1996-2001, Labour Economics, 17(1), 1-15.

Liu, R. and D. Trefler, 2008, Much Ado About Nothing: American Jobs and the Rise of Service Outsourcing to China and India, NBER Working Paper 14061

OECD, 2002, OECD Employment Outlook 2002, OECD Publishing.

OECD, 2004, OECD Employment Outlook 2004, OECD Publishing.

OECD, 2008, OECD Employment Outlook 2008, OECD Publishing.

Rodrik, D., 1997, Has globalization gone too far? Washington, DC: Institute for International Economics

Scheve, K. and M.J. Slaughter, 2004, Economic insecurity and the globalization of production, American Journal of Political Science, 48, 662-674

Schwörer, T., 2012, Offshoring, Domestic Outsourcing, and Productivity: Evidence for a Number of European Countries, Review of World Economics, forthcoming.

Timmer, M., 2012, The World Input-Output Database (WIOD): Contents, Sources and Methods, WIOD Working Paper 10

Wagner, G.G., J.R. Frick and J. Schupp, 2007, The German Socio-Economic Panel Study (SOEP) - Scope, Evolution and Enhancements. Schmollers Jahrbuch, 127, 139-169

Yi, K.M., 2003, Can Vertical Specialization Explain the Growth of World Trade?, Journal of Political Economy, 111, 52-102 


\section{Appendix}

\section{A1: Calculation of offshoring measures (imported intermediate inputs)}

This definition of outsourcing measures follows the initial work by Feenstra and Hanson (1999) and recent work using WIOD by Schwörer (2012). Offshoring is measured as the value of an industry's imported intermediate inputs from industries in country $c$ abroad as a share of the domestic industry's output. We can observe the amount of inputs that are imported for each industry by source country and industry directly from the World Input Output Database.

Formally, offshoring from country $c$ in domestic industry $j$ in year $t$ is defined as

$$
\mathrm{OFF}_{\mathrm{jct}}=\sum \mathrm{IMP}_{\mathrm{kct}} / \mathrm{Y}_{\mathrm{jct}}
$$

where $I M P$ are imported intermediates in domestic industry $\mathrm{j}$ from foreign industry $k$ in source country $c$, and $Y$ is industry output.

Based on this formula we calculate two different measures:

1. Materials offshoring, where $\mathrm{k}$ only includes manufacturing industries abroad

2. Services offshoring, where k only includes services industries abroad

The source countries $c$ are aggregated to non-OECD and OECD countries. Data are available annually and are obtained from the World Input Output Database for the period 1999 to 2009. 


\section{A2: Data, variable definitions and summary statistics for econometric analysis}

The econometric analysis is based on the German Socio-Economic Panel (SOEP), waves 1999 to 2009. We use all samples for the analysis. Yearly industry-level information about trade and offshoring is merged with the SOEP on basis of industry classification provided in the SOEP (NACE 1.1). Variables are defined as follows.

\begin{tabular}{|c|c|}
\hline Variable & SOEP variable and modifications \\
\hline Log real monthly gross wage & $\begin{array}{l}\text { Gross monthly income (LABGRO\$) deflated by CPI (German } \\
\text { Statistical Office). Imputed incomes are not used. }\end{array}$ \\
\hline Job loss & $\begin{array}{l}\text { Dummy for job loss is set to } 1 \text { in period } t \text { if person is unemployed in } t \\
\text { (LFS\$) and was working full time in } t-1 \text { (EMPLST\$). For } \\
\text { unemployed persons, no industry information is provided in period } t \text {. } \\
\text { We replace the missing value in } t \text { by the values in } t-1 \text {. }\end{array}$ \\
\hline Married & Dummy $=1$ if person is married (\$FAMSTD) \\
\hline Tenure & Number of years with employer (\$ERWZEIT) \\
\hline Public ownership & Dummy = 1 if employer is public service (OEFFD\$) \\
\hline Firm size & $\begin{array}{l}\text { Firm size categories (ALLBET\$): } \\
\begin{aligned} \text { 1. less than } 20 \text { employees (omitted category) } \\
\text { 2. greater/equal } 20 \text { and less than } 200 \text { employees } \\
\text { 3. greater/equal } 200 \text { and less than } 2000 \text { employees } \\
\text { 4. greater/equal } 2000 \text { employees } \\
\text { 5. } \text { self-employed without coworkers }\end{aligned}\end{array}$ \\
\hline Education & $\begin{array}{l}\text { Highest educational level obtained (ISCED\$): } \\
\text { 1. unqualified labour, up to secondary education (ISCED } 1 \text { \& 2) } \\
\text { 2. skilled labour, apprenticeship, vocational education (ISCED } 3 \\
\text { \& 4) } \\
\text { 3. high-skilled labour, tertiary education (ISCED } 5 \text { \& 6) }\end{array}$ \\
\hline Experience & $\begin{array}{l}\text { Years of work experience; one year of full-time work (EXPFT\$) } \\
\text { counts as } 1 \text { year, one year of part-time work (EXPPT\$) counts as } 0.5 \\
\text { year. }\end{array}$ \\
\hline East Germany & Dummy for Eastern federal state (BULA\$) \\
\hline Industry production & $\begin{array}{l}\text { Taken from WIOD Supply and Use tables. See discussion of } \\
\text { offshoring measures. }\end{array}$ \\
\hline$R \& D$ expenditure & $\begin{array}{l}\text { Taken from the Analytical Business Enterprise Research and } \\
\text { Development (ANBERD) database provided by the OECD. Series } \\
\text { runs until 2008. Values for } 2009 \text { are extrapolated. }\end{array}$ \\
\hline
\end{tabular}


A3: Tests after IV estimation of equation (1), excluding variable for temporary contract and interaction

\begin{tabular}{|c|c|}
\hline & $\begin{array}{l}\text { Instrumented: } \\
\text { Material offsh. } \\
\text { Service offsh. }\end{array}$ \\
\hline \multirow[t]{2}{*}{ Instruments } & $\begin{array}{l}\text { World material } \\
\text { offsh. at } t=-1\end{array}$ \\
\hline & $\begin{array}{c}\text { World material } \\
\text { offsh. at } t=-2\end{array}$ \\
\hline \multicolumn{2}{|c|}{ First stage F-test } \\
\hline F-statistic & 324.54 \\
\hline p-value & $(0.000)$ \\
\hline \multicolumn{2}{|c|}{ Underidentification test } \\
\hline$\chi^{2}$-statistic & 622.89 \\
\hline p-value & $(0.000)$ \\
\hline \multicolumn{2}{|c|}{ Test for exogeneity of regressor } \\
\hline$\chi^{2}$-statistic & 0.679 \\
\hline p-value & $(0.712)$ \\
\hline
\end{tabular}


A4: Detailed regression results

Table A1 - Fixed-effects regressions on log hourly wages, only manufacturing

\begin{tabular}{|c|c|c|c|c|}
\hline & $\begin{array}{c}\text { (1) } \\
\text { Total offshoring } \\
\end{array}$ & $\begin{array}{c}\text { (2) } \\
\text { Total offshoring } \\
\end{array}$ & $\begin{array}{c}(3) \\
\text { Offshoring to } \\
\text { non-OECD }\end{array}$ & $\begin{array}{c}(4) \\
\text { Offshoring to } \\
\text { OECD } \\
\end{array}$ \\
\hline Temporary contract & & $\begin{array}{l}0.128 * * \\
(0.0531)\end{array}$ & $\begin{array}{c}0.0627 \\
(0.0442)\end{array}$ & $\begin{array}{l}0.130 * * \\
(0.0480)\end{array}$ \\
\hline Material offsh. & $\begin{array}{c}0.00305 \\
(0.00235)\end{array}$ & $\begin{array}{c}0.00269 \\
(0.00218)\end{array}$ & $\begin{array}{c}0.0119 * \\
(0.00622)\end{array}$ & $\begin{array}{c}0.00119 \\
(0.00290)\end{array}$ \\
\hline Temp*Materials & & $\begin{array}{c}-0.00966^{* * *} \\
(0.00291)\end{array}$ & $\begin{array}{l}-0.0293^{* * *} \\
(0.00884)\end{array}$ & $\begin{array}{l}-0.0112^{* *} \\
(0.00396)\end{array}$ \\
\hline Services offsh. & $\begin{array}{l}-0.0128 \\
(0.0258)\end{array}$ & $\begin{array}{c}-0.00405 \\
(0.0245)\end{array}$ & $\begin{array}{l}-0.0117 \\
(0.0292)\end{array}$ & $\begin{array}{c}0.0105 \\
(0.0382)\end{array}$ \\
\hline Temp*Services & & $\begin{array}{l}-0.0150 \\
(0.0201)\end{array}$ & $\begin{array}{l}-0.00334 \\
(0.0433)\end{array}$ & $\begin{array}{l}-0.0435 \\
(0.0311)\end{array}$ \\
\hline Secondary educ. & $\begin{array}{c}0.0166 \\
(0.0114)\end{array}$ & $\begin{array}{c}0.0166 \\
(0.0131)\end{array}$ & $\begin{array}{c}0.0164 \\
(0.0131)\end{array}$ & $\begin{array}{c}0.0169 \\
(0.0132)\end{array}$ \\
\hline Tertiary educ. & $\begin{array}{l}0.0597^{* * *} \\
(0.0150)\end{array}$ & $\begin{array}{l}0.0710^{* * *} \\
(0.0168)\end{array}$ & $\begin{array}{l}0.0698^{* * *} \\
(0.0171)\end{array}$ & $\begin{array}{l}0.0715^{* * *} \\
(0.0165)\end{array}$ \\
\hline Married & $\begin{array}{c}0.0163 \\
(0.0108)\end{array}$ & $\begin{array}{c}0.0173 \\
(0.0105)\end{array}$ & $\begin{array}{c}0.0178 \\
(0.0104)\end{array}$ & $\begin{array}{c}0.0170 \\
(0.0106)\end{array}$ \\
\hline Tenure & $\begin{array}{l}0.00236^{* * *} \\
(0.000710)\end{array}$ & $\begin{array}{c}0.00197^{*} \\
(0.00103)\end{array}$ & $\begin{array}{l}0.00195^{*} \\
(0.00102)\end{array}$ & $\begin{array}{c}0.00202^{*} \\
(0.00102)\end{array}$ \\
\hline Public employer & $\begin{array}{c}0.0102 \\
(0.0263)\end{array}$ & $\begin{array}{c}0.0157 \\
(0.0283)\end{array}$ & $\begin{array}{c}0.0162 \\
(0.0281)\end{array}$ & $\begin{array}{c}0.0153 \\
(0.0282)\end{array}$ \\
\hline Firm size: 20-200 & $\begin{array}{c}0.0241 \\
(0.0157)\end{array}$ & $\begin{array}{c}0.0232^{*} \\
(0.0123)\end{array}$ & $\begin{array}{c}0.0237^{*} \\
(0.0122)\end{array}$ & $\begin{array}{c}0.0228^{*} \\
(0.0123)\end{array}$ \\
\hline Firm size: 200-2000 & $\begin{array}{l}0.0433^{* * *} \\
(0.0136)\end{array}$ & $\begin{array}{l}0.0414^{* *} \\
(0.0144)\end{array}$ & $\begin{array}{l}0.0415^{* *} \\
(0.0141)\end{array}$ & $\begin{array}{l}0.0411^{* *} \\
(0.0145)\end{array}$ \\
\hline Firm size: > 2000 & $\begin{array}{l}0.0518^{* * *} \\
(0.0108)\end{array}$ & $\begin{array}{l}0.0499^{* * *} \\
(0.0160)\end{array}$ & $\begin{array}{l}0.0502^{* * *} \\
(0.0156)\end{array}$ & $\begin{array}{l}0.0495^{* * *} \\
(0.0162)\end{array}$ \\
\hline Firm size: self-empl. & $\begin{array}{c}0.0594 \\
(0.0996)\end{array}$ & $\begin{array}{c}0.0447 \\
(0.0310)\end{array}$ & $\begin{array}{c}0.0424 \\
(0.0367)\end{array}$ & $\begin{array}{c}0.0480 \\
(0.0278)\end{array}$ \\
\hline Experience & $\begin{array}{l}0.0331^{* *} \\
(0.0123)\end{array}$ & $\begin{array}{l}0.0280^{* *} \\
(0.0110)\end{array}$ & $\begin{array}{l}0.0277^{* *} \\
(0.0114)\end{array}$ & $\begin{array}{l}0.0283^{* *} \\
(0.0108)\end{array}$ \\
\hline Experience squared & $\begin{array}{l}-0.000352^{* * *} \\
(0.0000613)\end{array}$ & $\begin{array}{l}-0.000322^{* * *} \\
(0.0000644)\end{array}$ & $\begin{array}{l}-0.000325^{* * *} \\
(0.0000640)\end{array}$ & $\begin{array}{l}-0.000321^{* * *} \\
(0.0000635)\end{array}$ \\
\hline Industry production & $\begin{array}{c}8.20 \mathrm{e}-08 \\
(0.000000136)\end{array}$ & $\begin{array}{c}0.000000154 \\
(0.000000138)\end{array}$ & $\begin{array}{c}0.000000162 \\
(0.000000115)\end{array}$ & $\begin{array}{c}0.000000206 \\
(0.000000145)\end{array}$ \\
\hline $\mathrm{R} \& \mathrm{D}$ & $\begin{array}{c}0.00000427 \\
(0.00000329)\end{array}$ & $\begin{array}{c}0.00000163 \\
(0.00000215)\end{array}$ & $\begin{array}{c}0.00000194 \\
(0.00000194)\end{array}$ & $\begin{array}{c}0.000000839 \\
(0.00000196)\end{array}$ \\
\hline East & $\begin{array}{c}-0.0708 \\
(0.0447)\end{array}$ & $\begin{array}{c}-0.0639 \\
(0.0469)\end{array}$ & $\begin{array}{c}-0.0627 \\
(0.0474)\end{array}$ & $\begin{array}{c}-0.0645 \\
(0.0466)\end{array}$ \\
\hline Constant & $\begin{array}{l}2.150^{* * *} \\
(0.148) \\
\end{array}$ & $\begin{array}{l}2.168^{* * *} \\
(0.130) \\
\end{array}$ & $\begin{array}{l}2.184^{* * *} \\
(0.143) \\
\end{array}$ & $\begin{array}{l}2.151^{* * *} \\
(0.130) \\
\end{array}$ \\
\hline \# obs. (\# groups) & $18261(4071)$ & 17341 (3893) & 17341 (3893) & 17341 (3893) \\
\hline$R 2$ adj. & 0.811 & 0.828 & 0.828 & 0.828 \\
\hline
\end{tabular}

Note: Cluster robust standard errors in parentheses; ${ }^{*} p<0.10,{ }^{* *} p<0.05,{ }^{* * *} p<0.01$; regressions include year dummies, industry dummies, and industry-specific time trends. 
Table A2 - Probit regressions on job loss indicator, only manufacturing

\begin{tabular}{|c|c|c|c|c|}
\hline & $\begin{array}{l}\text { (1) } \\
\text { Total offshoring }\end{array}$ & $\begin{array}{c}\text { (2) } \\
\text { Total offshoring }\end{array}$ & $\begin{array}{c}\text { (3) } \\
\text { Offshoring to } \\
\text { non-OECD }\end{array}$ & $\begin{array}{c}\text { (4) } \\
\text { Offshoring to } \\
\text { OECD }\end{array}$ \\
\hline Temporary contract & & $\begin{array}{l}0.603^{* *} \\
(0.282)\end{array}$ & $\begin{array}{l}0.592^{* * *} \\
(0.108)\end{array}$ & $\begin{array}{c}0.568 \\
(0.561)\end{array}$ \\
\hline Material offsh. & $\begin{array}{l}-0.0621^{* *} \\
(0.0308)\end{array}$ & $\begin{array}{l}-0.0612^{* *} \\
(0.0298)\end{array}$ & $\begin{array}{l}-0.179^{* *} \\
(0.0887)\end{array}$ & $\begin{array}{l}-0.0977^{* *} \\
(0.0465)\end{array}$ \\
\hline Temp*Materials & & $\begin{array}{c}0.0128^{*} \\
(0.00658)\end{array}$ & $\begin{array}{l}0.0519^{* * *} \\
(0.0179)\end{array}$ & $\begin{array}{c}0.0131 \\
(0.0136)\end{array}$ \\
\hline Services offsh. & $\begin{array}{l}-0.672 \\
(0.459)\end{array}$ & $\begin{array}{l}-0.803 \\
(0.533)\end{array}$ & $\begin{array}{l}-0.114 \\
(0.312)\end{array}$ & $\begin{array}{l}-0.751 \\
(0.578)\end{array}$ \\
\hline Temp*Services & & $\begin{array}{l}-0.162 \\
(0.199)\end{array}$ & $\begin{array}{l}-0.446^{* *} \\
(0.201)\end{array}$ & $\begin{array}{l}-0.152 \\
(0.544)\end{array}$ \\
\hline Secondary educ. & $\begin{array}{l}-0.234^{* * *} \\
(0.0598)\end{array}$ & $\begin{array}{l}-0.204^{* * *} \\
(0.0616)\end{array}$ & $\begin{array}{l}-0.203^{* * *} \\
(0.0615)\end{array}$ & $\begin{array}{l}-0.204^{* * *} \\
(0.0617)\end{array}$ \\
\hline Tertiary educ. & $\begin{array}{l}-0.477^{* * *} \\
(0.0592)\end{array}$ & $\begin{array}{l}-0.412^{* * *} \\
(0.0530)\end{array}$ & $\begin{array}{l}-0.411^{* * *} \\
(0.0529)\end{array}$ & $\begin{array}{l}-0.410^{* * *} \\
(0.0535)\end{array}$ \\
\hline Married & $\begin{array}{c}-0.114 \\
(0.0753)\end{array}$ & $\begin{array}{l}-0.116 \\
(0.0787)\end{array}$ & $\begin{array}{c}-0.116 \\
(0.0781)\end{array}$ & $\begin{array}{c}-0.116 \\
(0.0785)\end{array}$ \\
\hline Tenure & $\begin{array}{l}-0.0288^{* * *} \\
(0.00275)\end{array}$ & $\begin{array}{l}-0.0243^{* * *} \\
(0.00280)\end{array}$ & $\begin{array}{l}-0.0245^{* * *} \\
(0.00282)\end{array}$ & $\begin{array}{l}-0.0243^{* * *} \\
(0.00280)\end{array}$ \\
\hline Public employer & $\begin{array}{l}-0.301^{* *} \\
(0.131)\end{array}$ & $\begin{array}{l}-0.214 \\
(0.194)\end{array}$ & $\begin{array}{l}-0.213 \\
(0.192)\end{array}$ & $\begin{array}{l}-0.217 \\
(0.196)\end{array}$ \\
\hline Firm size: 20-200 & $\begin{array}{c}0.0315 \\
(0.0658)\end{array}$ & $\begin{array}{l}-0.0268 \\
(0.0651)\end{array}$ & $\begin{array}{l}-0.0255 \\
(0.0644)\end{array}$ & $\begin{array}{l}-0.0282 \\
(0.0650)\end{array}$ \\
\hline Firm size: 200-2000 & $\begin{array}{l}-0.0975 \\
(0.0890)\end{array}$ & $\begin{array}{l}-0.171^{* *} \\
(0.0789)\end{array}$ & $\begin{array}{l}-0.168^{* *} \\
(0.0785)\end{array}$ & $\begin{array}{l}-0.171^{* *} \\
(0.0787)\end{array}$ \\
\hline Firm size: > 2000 & $\begin{array}{l}-0.204^{* *} \\
(0.0829)\end{array}$ & $\begin{array}{l}-0.287^{* * *} \\
(0.0952)\end{array}$ & $\begin{array}{l}-0.286^{* * *} \\
(0.0952)\end{array}$ & $\begin{array}{l}-0.288^{* * *} \\
(0.0953)\end{array}$ \\
\hline Firm size: self-empl. & $\begin{array}{l}-0.462^{*} \\
(0.238)\end{array}$ & & & \\
\hline Experience & $\begin{array}{c}-0.0243^{* *} \\
(0.0116)\end{array}$ & $\begin{array}{c}-0.0132 \\
(0.0116)\end{array}$ & $\begin{array}{c}-0.0130 \\
(0.0116)\end{array}$ & $\begin{array}{c}-0.0133 \\
(0.0116)\end{array}$ \\
\hline Experience squared & $\begin{array}{l}0.00106^{* * *} \\
(0.000227)\end{array}$ & $\begin{array}{c}0.000857^{* * *} \\
(0.000225)\end{array}$ & $\begin{array}{c}0.000855^{* * *} \\
(0.000223)\end{array}$ & $\begin{array}{c}0.000857^{* * *} \\
(0.000226)\end{array}$ \\
\hline Industry production & $\begin{array}{c}0.00000202 \\
(0.00000153)\end{array}$ & $\begin{array}{c}0.00000265 \\
(0.00000167)\end{array}$ & $\begin{array}{c}0.00000308^{*} \\
(0.00000177)\end{array}$ & $\begin{array}{c}0.00000330^{*} \\
(0.00000183)\end{array}$ \\
\hline $\mathrm{R} \& \mathrm{D}$ & $\begin{array}{l}0.00000409 \\
(0.0000268)\end{array}$ & $\begin{array}{c}0.0000135 \\
(0.0000327)\end{array}$ & $\begin{array}{l}-0.0000106 \\
(0.0000327)\end{array}$ & $\begin{array}{c}0.0000270 \\
(0.0000452)\end{array}$ \\
\hline East & $\begin{array}{l}0.104^{* * *} \\
(0.0323)\end{array}$ & $\begin{array}{l}0.0862^{* *} \\
(0.0348)\end{array}$ & $\begin{array}{l}0.0866^{* *} \\
(0.0354)\end{array}$ & $\begin{array}{l}0.0865^{* *} \\
(0.0351)\end{array}$ \\
\hline Constant & $\begin{array}{c}-27.84 \\
(32.63) \\
\end{array}$ & $\begin{array}{c}-9.264 \\
(37.20) \\
\end{array}$ & $\begin{array}{c}53.03 \\
(39.27) \\
\end{array}$ & $\begin{array}{l}-3.497 \\
(34.77) \\
\end{array}$ \\
\hline \#obs. & 17594 & 16597 & 16597 & 16597 \\
\hline Pseudo R2 & 0.095 & 0.112 & 0.112 & 0.111 \\
\hline
\end{tabular}

Note: Cluster robust standard errors in parentheses; ${ }^{*} p<0.10,{ }^{* *} p<0.05,{ }^{* * *} p<0.01$; regressions include year dummies, industry dummies, and industry-specific time trends. Firm size: self-empl. predicts failure perfectly in specification (2) to (4) and is thus excluded. 
Table A3 - Fixed-effects regressions on log hourly wages, only services

\begin{tabular}{|c|c|c|c|c|}
\hline & $\begin{array}{c}\text { (1) } \\
\text { Total offshoring }\end{array}$ & $\begin{array}{c}\text { (2) } \\
\text { Total offshoring }\end{array}$ & $\begin{array}{c}\text { (3) } \\
\text { Offshoring to } \\
\text { non-OECD }\end{array}$ & $\begin{array}{c}\text { (4) } \\
\text { Offshoring to } \\
\text { OECD }\end{array}$ \\
\hline Temporary contract & & $\begin{array}{c}0.0244 \\
(0.0424)\end{array}$ & $\begin{array}{c}0.0390 \\
(0.0369)\end{array}$ & $\begin{array}{l}0.00951 \\
(0.0402)\end{array}$ \\
\hline Material offsh. & $\begin{array}{l}0.0156^{* * *} \\
(0.00375)\end{array}$ & $\begin{array}{c}0.00838 \\
(0.00544)\end{array}$ & $\begin{array}{c}0.0281 \\
(0.0207)\end{array}$ & $\begin{array}{c}0.00886 \\
(0.00647)\end{array}$ \\
\hline Temp*Materials & & $\begin{array}{l}-0.00604 \\
(0.00824)\end{array}$ & $\begin{array}{l}-0.0399 \\
(0.0296)\end{array}$ & $\begin{array}{l}-0.00566 \\
(0.00983)\end{array}$ \\
\hline Services offsh. & $\begin{array}{c}0.0164 \\
(0.0136)\end{array}$ & $\begin{array}{c}0.0118 \\
(0.0133)\end{array}$ & $\begin{array}{c}0.0212 \\
(0.0233)\end{array}$ & $\begin{array}{c}0.0107 \\
(0.0149)\end{array}$ \\
\hline Temp*Services & & $\begin{array}{l}-0.0199^{*} \\
(0.0104)\end{array}$ & $\begin{array}{l}-0.102^{* *} \\
(0.0403)\end{array}$ & $\begin{array}{l}-0.0214 \\
(0.0127)\end{array}$ \\
\hline Secondary educ. & $\begin{array}{c}0.0110 \\
(0.0253)\end{array}$ & $\begin{array}{l}-0.00948 \\
(0.0269)\end{array}$ & $\begin{array}{r}-0.00932 \\
(0.0268)\end{array}$ & $\begin{array}{l}-0.00966 \\
(0.0269)\end{array}$ \\
\hline Tertiary educ. & $\begin{array}{c}0.0485 \\
(0.0373)\end{array}$ & $\begin{array}{c}0.0327 \\
(0.0364)\end{array}$ & $\begin{array}{c}0.0326 \\
(0.0364)\end{array}$ & $\begin{array}{c}0.0329 \\
(0.0364)\end{array}$ \\
\hline Married & $\begin{array}{c}0.0165^{*} \\
(0.00781)\end{array}$ & $\begin{array}{c}0.0148 \\
(0.0160)\end{array}$ & $\begin{array}{c}0.0152 \\
(0.0160)\end{array}$ & $\begin{array}{c}0.0146 \\
(0.0160)\end{array}$ \\
\hline Tenure & $\begin{array}{l}0.00337^{* *} \\
(0.00143)\end{array}$ & $\begin{array}{l}0.00313^{* *} \\
(0.00107)\end{array}$ & $\begin{array}{l}0.00303^{* *} \\
(0.00109)\end{array}$ & $\begin{array}{l}0.00317^{* *} \\
(0.00107)\end{array}$ \\
\hline Public employer & $\begin{array}{l}-0.0263^{* *} \\
(0.0118)\end{array}$ & $\begin{array}{l}-0.0158 \\
(0.0133)\end{array}$ & $\begin{array}{l}-0.0158 \\
(0.0134)\end{array}$ & $\begin{array}{l}-0.0156 \\
(0.0133)\end{array}$ \\
\hline Firm size: $20-200$ & $\begin{array}{l}0.0505^{* * *} \\
(0.0104)\end{array}$ & $\begin{array}{l}0.0489^{* * * *} \\
(0.0118)\end{array}$ & $\begin{array}{l}0.0490^{* * *} \\
(0.0119)\end{array}$ & $\begin{array}{l}0.0490^{* * *} \\
(0.0118)\end{array}$ \\
\hline Firm size: $200-2000$ & $\begin{array}{l}0.0279^{* * *} \\
(0.0124)\end{array}$ & $\begin{array}{l}0.0389^{* * *} \\
(0.0169)\end{array}$ & $\begin{array}{l}0.0390^{* *} \\
(0.0170)\end{array}$ & $\begin{array}{l}0.0388^{* *} \\
(0.0169)\end{array}$ \\
\hline Firm size: > 2000 & $\begin{array}{l}0.0351^{*} \\
(0.0183)\end{array}$ & $\begin{array}{l}0.0530^{* * *} \\
(0.0177)\end{array}$ & $\begin{array}{l}0.0524^{* *} \\
(0.0179)\end{array}$ & $\begin{array}{l}0.0531^{* *} \\
(0.0177)\end{array}$ \\
\hline Firm size: self-empl. & $\begin{array}{c}0.0323 \\
(0.0311)\end{array}$ & $\begin{array}{c}0.0630 \\
(0.0595)\end{array}$ & $\begin{array}{c}0.0617 \\
(0.0594)\end{array}$ & $\begin{array}{c}0.0626 \\
(0.0592)\end{array}$ \\
\hline Experience & $\begin{array}{l}0.0586^{* * *} \\
(0.0145)\end{array}$ & $\begin{array}{c}0.0579^{* * *} \\
(0.0116)\end{array}$ & $\begin{array}{c}0.0571^{* * *} \\
(0.0117)\end{array}$ & $\begin{array}{c}0.0584^{* * *} \\
(0.0117)\end{array}$ \\
\hline Experience squared & $\begin{array}{l}-0.000437^{* * *} \\
(0.0000885)\end{array}$ & $\begin{array}{l}-0.000454^{* * *} \\
(0.0000483)\end{array}$ & $\begin{array}{l}-0.000454^{* * *} \\
(0.0000483)\end{array}$ & $\begin{array}{l}-0.000454^{* * *} \\
(0.0000481)\end{array}$ \\
\hline Industry production & $\begin{array}{l}0.000000154^{*} \\
(7.23 \mathrm{e}-08)\end{array}$ & $\begin{array}{c}8.43 \mathrm{e}-08 \\
(9.31 \mathrm{e}-08)\end{array}$ & $\begin{array}{c}7.68 \mathrm{e}-08 \\
(0.000000104)\end{array}$ & $\begin{array}{c}5.77 \mathrm{e}-08 \\
(9.24 \mathrm{e}-08)\end{array}$ \\
\hline$R \& D$ & $\begin{array}{l}0.0000287^{* * *} \\
(0.00000726)\end{array}$ & $\begin{array}{l}0.0000231^{* * *} \\
(0.00000538)\end{array}$ & $\begin{array}{c}0.0000206^{* *} \\
(0.00000924)\end{array}$ & $\begin{array}{l}0.0000241^{* * *} \\
(0.00000522)\end{array}$ \\
\hline East & $\begin{array}{l}-0.126 \\
(0.0732)\end{array}$ & $\begin{array}{l}-0.0342 \\
(0.0364)\end{array}$ & $\begin{array}{l}-0.0339 \\
(0.0355)\end{array}$ & $\begin{array}{l}-0.0340 \\
(0.0368)\end{array}$ \\
\hline Constant & $\begin{array}{l}1.741^{* * *} \\
(0.233)\end{array}$ & $\begin{array}{l}1.780^{* * *} \\
(0.183)\end{array}$ & $\begin{array}{l}1.802^{* * *} \\
(0.171)\end{array}$ & $\begin{array}{l}1.792^{* * *} \\
(0.187)\end{array}$ \\
\hline $\begin{array}{l}\text { \# obs. (\# groups) } \\
\text { R2 adj. }\end{array}$ & $\begin{array}{c}23208(5416) \\
0.778\end{array}$ & $\begin{array}{c}18902(4746) \\
0.844\end{array}$ & $\begin{array}{c}18902(4746) \\
0.844\end{array}$ & $\begin{array}{c}18902(4746) \\
0.844\end{array}$ \\
\hline
\end{tabular}

Note: Cluster robust standard errors in parentheses; ${ }^{*} p<0.10,{ }^{* *} p<0.05,{ }^{* * *} p<0.01$; regressions include year dummies, industry dummies, and industry-specific time trends. 
Table A4 - Probit regressions on job loss indicator, only services

\begin{tabular}{|c|c|c|c|c|}
\hline & $\begin{array}{l}\text { (1) } \\
\text { Total offshoring } \\
\end{array}$ & $\begin{array}{c}\text { (2) } \\
\text { Total offshoring }\end{array}$ & $\begin{array}{c}\text { (3) } \\
\text { Offshoring to } \\
\text { non-OECD }\end{array}$ & $\begin{array}{c}\text { (4) } \\
\text { Offshoring to } \\
\text { OECD } \\
\end{array}$ \\
\hline Temporary contract & & $\begin{array}{l}0.601^{\text {*** }} \\
(0.103)\end{array}$ & $\begin{array}{l}0.541^{* * *} \\
(0.0982)\end{array}$ & $\begin{array}{l}0.604^{* * *} \\
(0.0997)\end{array}$ \\
\hline Material offsh. & $\begin{array}{c}0.0138 \\
(0.0669)\end{array}$ & $\begin{array}{c}0.0262 \\
(0.0622)\end{array}$ & $\begin{array}{c}0.219 \\
(0.274)\end{array}$ & $\begin{array}{l}0.00886 \\
(0.0610)\end{array}$ \\
\hline Temp*Materials & & $\begin{array}{l}-0.0296^{* * *} \\
(0.00783)\end{array}$ & $\begin{array}{l}-0.0676 \\
(0.0750)\end{array}$ & $\begin{array}{l}-0.0388^{* * * *} \\
(0.00948)\end{array}$ \\
\hline Services offsh. & $\begin{array}{l}-0.0524 \\
(0.0907)\end{array}$ & $\begin{array}{l}-0.0918 \\
(0.112)\end{array}$ & $\begin{array}{c}0.197 \\
(0.143)\end{array}$ & $\begin{array}{l}-0.168^{*} \\
(0.100)\end{array}$ \\
\hline Temp*Services & & $\begin{array}{l}-0.0140 \\
(0.0187)\end{array}$ & $\begin{array}{l}-0.0319 \\
(0.104)\end{array}$ & $\begin{array}{l}-0.0177 \\
(0.0214)\end{array}$ \\
\hline Secondary educ. & $\begin{array}{l}-0.238^{* * *} \\
(0.0285)\end{array}$ & $\begin{array}{l}-0.183^{* * *} \\
(0.0351)\end{array}$ & $\begin{array}{l}-0.179^{* * *} \\
(0.0358)\end{array}$ & $\begin{array}{l}-0.184^{* * *} \\
(0.0346)\end{array}$ \\
\hline Tertiary educ. & $\begin{array}{l}-0.609^{* * *} \\
(0.0524)\end{array}$ & $\begin{array}{l}-0.483^{* * *} \\
(0.0495)\end{array}$ & $\begin{array}{l}-0.479^{* * *} \\
(0.0496)\end{array}$ & $\begin{array}{l}-0.484^{* * *} \\
(0.0492)\end{array}$ \\
\hline Married & $\begin{array}{l}-0.0776^{* *} \\
(0.0381)\end{array}$ & $\begin{array}{l}-0.102^{* * *} \\
(0.0373)\end{array}$ & $\begin{array}{l}-0.102^{* * *} \\
(0.0370)\end{array}$ & $\begin{array}{l}-0.102^{* * *} \\
(0.0372)\end{array}$ \\
\hline Tenure & $\begin{array}{l}-0.0358^{* * *} \\
(0.00411)\end{array}$ & $\begin{array}{l}-0.0275^{* * *} \\
(0.00388)\end{array}$ & $\begin{array}{l}-0.0275^{* * *} \\
(0.00388)\end{array}$ & $\begin{array}{l}-0.0275^{* * *} \\
(0.00390)\end{array}$ \\
\hline Public employer & $\begin{array}{l}0.0729 \\
(0.137)\end{array}$ & $\begin{array}{c}0.117 \\
(0.127)\end{array}$ & $\begin{array}{c}0.115 \\
(0.126)\end{array}$ & $\begin{array}{c}0.117 \\
(0.126)\end{array}$ \\
\hline Firm size: 20-200 & $\begin{array}{l}0.0719^{*} \\
(0.0410)\end{array}$ & $\begin{array}{l}-0.0375 \\
(0.0468)\end{array}$ & $\begin{array}{l}-0.0382 \\
(0.0469)\end{array}$ & $\begin{array}{l}-0.0369 \\
(0.0470)\end{array}$ \\
\hline Firm size: 200-2000 & $\begin{array}{c}0.0186 \\
(0.0500)\end{array}$ & $\begin{array}{l}-0.109^{*} \\
(0.0556)\end{array}$ & $\begin{array}{l}-0.112^{* *} \\
(0.0551)\end{array}$ & $\begin{array}{l}-0.109^{*} \\
(0.0561)\end{array}$ \\
\hline Firm size: > 2000 & $\begin{array}{c}-0.134 \\
(0.0828)\end{array}$ & $\begin{array}{l}-0.249^{* * *} \\
(0.0876)\end{array}$ & $\begin{array}{l}-0.248^{* * *} \\
(0.0876)\end{array}$ & $\begin{array}{l}-0.250^{* * *} \\
(0.0874)\end{array}$ \\
\hline Firm size: self-empl. & $\begin{array}{c}-0.394^{* * *} \\
(0.109)\end{array}$ & $\begin{array}{l}-0.576 \\
(0.463)\end{array}$ & $\begin{array}{c}-0.573 \\
(0.463)\end{array}$ & $\begin{array}{l}-0.577 \\
(0.462)\end{array}$ \\
\hline Experience & $\begin{array}{l}-0.0170^{* * *} \\
(0.00459)\end{array}$ & $\begin{array}{l}-0.0123^{* * *} \\
(0.00408)\end{array}$ & $\begin{array}{l}-0.0125^{* * *} \\
(0.00424)\end{array}$ & $\begin{array}{l}-0.0123^{* * *} \\
(0.00406)\end{array}$ \\
\hline Experience squared & $\begin{array}{l}0.000751^{* * *} \\
(0.0000894)\end{array}$ & $\begin{array}{c}0.000647^{* * *} \\
(0.0000936)\end{array}$ & $\begin{array}{l}0.000652^{* * *} \\
(0.0000987)\end{array}$ & $\begin{array}{l}0.000647^{* * *} \\
(0.0000928)\end{array}$ \\
\hline Industry production & $\begin{array}{c}-0.000000242 \\
(0.00000144)\end{array}$ & $\begin{array}{c}-0.000000276 \\
(0.00000125)\end{array}$ & $\begin{array}{l}0.000000645 \\
(0.00000130)\end{array}$ & $\begin{array}{r}-0.000000402 \\
(0.00000111)\end{array}$ \\
\hline $\mathrm{R} \& \mathrm{D}$ & $\begin{array}{l}0.00000887 \\
(0.0000539)\end{array}$ & $\begin{array}{l}-0.0000184 \\
(0.0000460)\end{array}$ & $\begin{array}{l}-0.0000447 \\
(0.0000431)\end{array}$ & $\begin{array}{l}-0.0000654^{*} \\
(0.0000388)\end{array}$ \\
\hline East & $\begin{array}{l}0.326^{* * *} \\
(0.0617)\end{array}$ & $\begin{array}{l}0.317^{* * *} \\
(0.0621)\end{array}$ & $\begin{array}{l}0.315^{* * *} \\
(0.0616)\end{array}$ & $\begin{array}{l}0.317^{* * *} \\
(0.0620)\end{array}$ \\
\hline Constant & $\begin{array}{l}-1.555^{* *} \\
(0.641)\end{array}$ & $\begin{array}{c}-1.643^{* * *} \\
(0.615)\end{array}$ & $\begin{array}{l}-2.505^{* * *} \\
(0.728)\end{array}$ & $\begin{array}{c}-1.494^{* * *} \\
(0.413)\end{array}$ \\
\hline $\begin{array}{l}\text { \# obs. } \\
\text { Pseudo R2 }\end{array}$ & $\begin{array}{c}23302 \\
0.126\end{array}$ & $\begin{array}{c}18563 \\
0.133\end{array}$ & $\begin{array}{c}18563 \\
0.133\end{array}$ & $\begin{array}{c}18563 \\
0.133\end{array}$ \\
\hline
\end{tabular}

Note: Cluster robust standard errors in parentheses; ${ }^{*} p<0.10,{ }^{* *} p<0.05,{ }^{* * *} p<0.01$; regressions include year dummies, and industry dummies. 
Figure 1: Offshoring, 1999 and 2009, by manufacturing industry, in percent of output
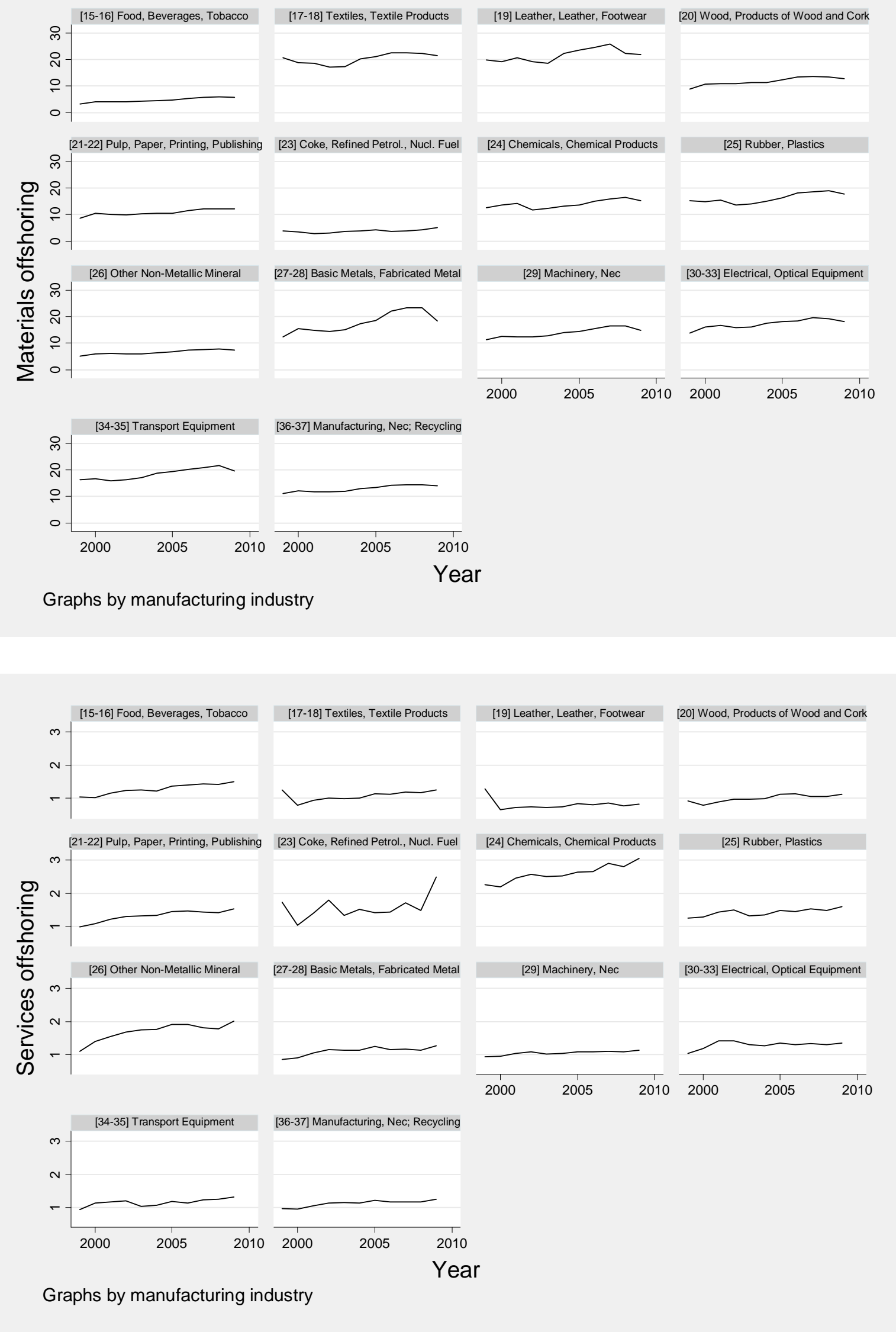
Figure 2: Offshoring, 1999 and 2009, by service industry, in percent of output
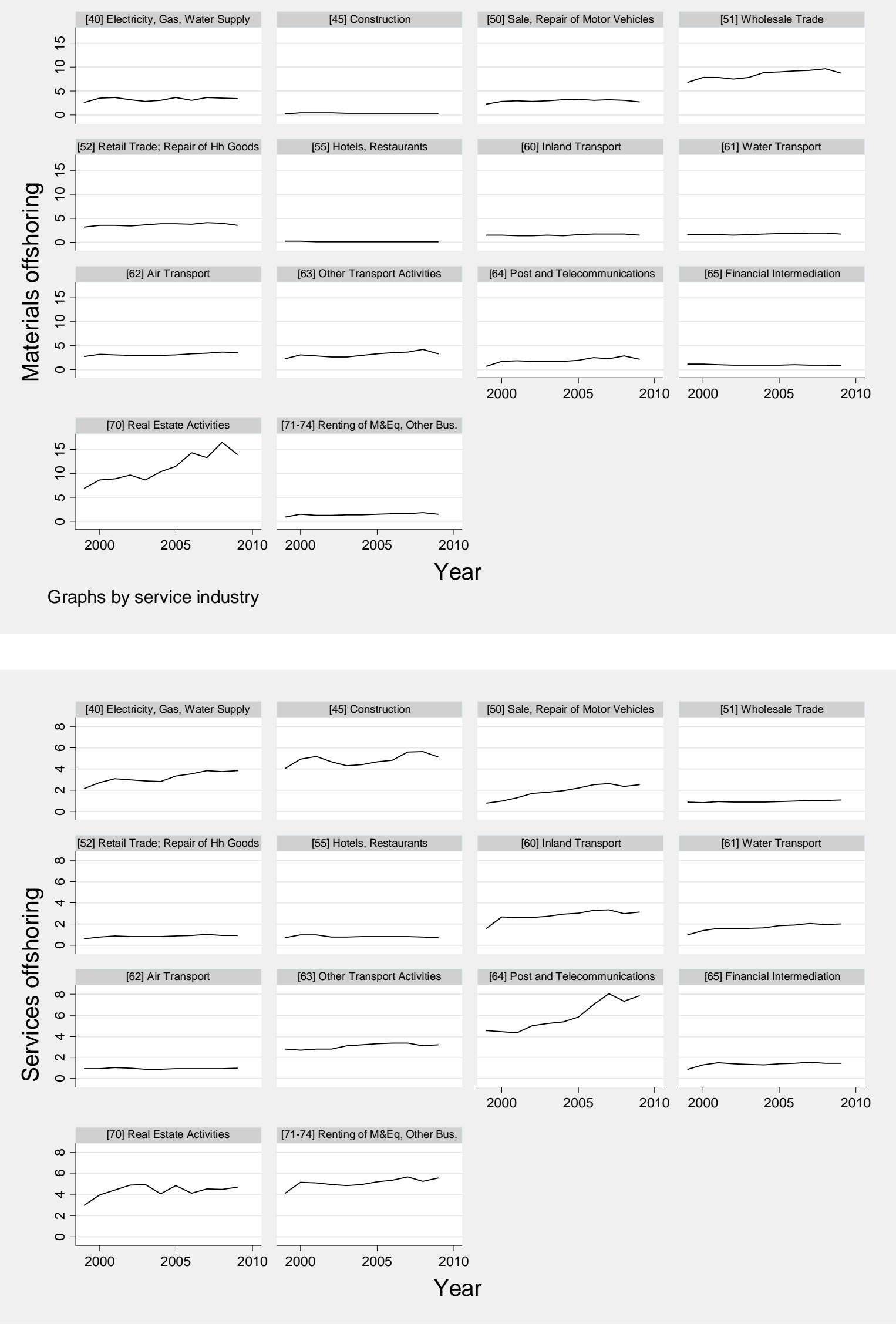
Table 1 - Incidence of temporary contracts, by country and age group

\begin{tabular}{|c|c|c|c|c|c|c|c|c|c|c|c|}
\hline & 1999 & 2000 & 2001 & 2002 & 2003 & 2004 & 2005 & 2006 & 2007 & 2008 & 2009 \\
\hline \multicolumn{12}{|c|}{ A. 15-64 years old } \\
\hline European Union & 13.3 & 13.6 & 13.5 & 13.2 & 13.1 & 13.5 & 14.5 & 15.1 & 14.6 & 14.1 & 13.6 \\
\hline Germany & 13.1 & 12.8 & 12.4 & 12.0 & 12.2 & 12.5 & 14.2 & 14.5 & 14.6 & 14.7 & 14.5 \\
\hline Denmark & 10.1 & 10.2 & 9.4 & 8.9 & 9.5 & 9.8 & 9.8 & 8.9 & 8.6 & 8.3 & 8.9 \\
\hline Spain & 32.8 & 32.4 & 32.1 & 32.1 & 31.8 & 32.1 & 33.4 & 34.1 & 31.7 & 29.3 & 25.5 \\
\hline France & 13.9 & 15.4 & 14.9 & 14.1 & 13.4 & 13.0 & 14.1 & 14.9 & 15.2 & 15.0 & 14.4 \\
\hline Italy & 9.8 & 10.1 & 9.6 & 9.9 & 9.5 & 11.9 & 12.3 & 13.1 & 13.2 & 13.3 & 12.5 \\
\hline United Kingdom & 6.7 & 6.6 & 6.6 & 6.0 & 5.7 & 5.6 & 5.7 & 5.7 & 5.7 & 5.3 & 5.5 \\
\hline United States & 4.5 & . & 4.0 & 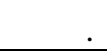 & & 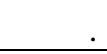 & 4.2 & & . & . & \\
\hline \multicolumn{12}{|c|}{ B. 15-24 years old (young workers) } \\
\hline European Union & 39.2 & 39.4 & 39.0 & 38.2 & 38.1 & 39.1 & 41.2 & 42.1 & 41.3 & 40.2 & 40.5 \\
\hline Germany & 53.1 & 52.4 & 52.1 & 51.4 & 53.0 & 55.5 & 58.0 & 57.6 & $\mathbf{5 7 . 5}$ & 56.6 & 57.2 \\
\hline Denmark & 29.7 & 29.8 & 26.9 & 25.0 & 27.3 & 26.9 & 26.9 & 22.4 & 22.2 & 23.2 & 23.6 \\
\hline Spain & 70.3 & 68.9 & 66.6 & 65.1 & 63.9 & 64.8 & 66.5 & 66.1 & 62.8 & 59.4 & 55.9 \\
\hline France & 54.4 & 55.0 & 52.2 & 48.5 & 47.4 & 47.8 & 50.7 & 52.2 & 53.9 & 52.9 & 52.7 \\
\hline Italy & 26.2 & 26.2 & 23.3 & 27.3 & 25.5 & 34.4 & 37.0 & 40.9 & 42.3 & 43.3 & 44.4 \\
\hline United Kingdom & 12.6 & 13.2 & 13.4 & 12.0 & 11.0 & 11.0 & 12.3 & 12.8 & 13.3 & 12.0 & 11.9 \\
\hline United States & 9.6 & ent & 8.1 & - & - & . & 8.1 & . & . & . & \\
\hline
\end{tabular}

Source: Eurostat (LFS), OECD Employment and Labour Market Statistics (for US)

Note: European Union refers to EU15 until 2004, EU25 until 2006, and EU27 thereafter.

Table 2 - Temporary work and education in Germany

\begin{tabular}{|c|c|c|c|c|c|c|c|c|c|c|c|}
\hline & 1999 & 2000 & 2001 & 2002 & 2003 & 2004 & 2005 & 2006 & 2007 & 2008 & 2009 \\
\hline \multicolumn{12}{|c|}{ A. $15-64$ years old } \\
\hline \multicolumn{12}{|c|}{ Incidence of temporary work by educational attainment } \\
\hline Primary & 26.8 & 27.5 & 27.8 & 27.9 & 29.2 & 29.8 & 30.4 & 30.4 & 31.9 & 32.6 & 33.0 \\
\hline Secondary & 8.6 & 8.4 & 8.0 & 7.9 & 7.9 & 8.0 & 9.7 & 10.0 & 10.2 & 10.5 & 10.3 \\
\hline Tertiary & 7.9 & 7.4 & 7.2 & 6.5 & 6.9 & 7.0 & 7.8 & 8.2 & 8.0 & 8.2 & 8.2 \\
\hline \multicolumn{12}{|c|}{ B. 15-24 years old (young workers) } \\
\hline \multicolumn{12}{|c|}{ Incidence of temporary work by educational attainment } \\
\hline Primary & 80.2 & 80.1 & 75.5 & 74.3 & 76.2 & 78.8 & 78.4 & 76.6 & 76.5 & 75.7 & 77.5 \\
\hline Secondary & 32.2 & 31.2 & 31.2 & 31.5 & 31.6 & 34.7 & 38.8 & 39.4 & 39.7 & 40.0 & 40.3 \\
\hline Tertiary & 26.7 & 30.7 & 29.1 & 26.2 & 28.3 & 29.7 & 32.5 & 36.5 & 38.0 & 37.2 & 35.6 \\
\hline
\end{tabular}

Source: Eurostat (LFS)

Note: Primary education refers to ISCED levels 0-2, secondary refers to ISCED levels 3-4, tertiary refers to ISCED level 5-6. 
Table 3 - Determinants of holding a temporary contract, probit regression

(1)

(2)

(3)

\begin{tabular}{|c|c|c|c|}
\hline & Total offshoring & $\begin{array}{l}\text { Offshoring to } \\
\text { non-OECD }\end{array}$ & $\begin{array}{l}\text { Offshoring to } \\
\text { OECD }\end{array}$ \\
\hline \multirow[t]{2}{*}{ Material offsh. } & -0.0103 & -0.0000918 & -0.0183 \\
\hline & $(0.0148)$ & $(0.0531)$ & $(0.0210)$ \\
\hline \multirow{2}{*}{ Services offsh. } & -0.0585 & -0.0590 & -0.0473 \\
\hline & $(0.0572)$ & $(0.182)$ & $(0.0512)$ \\
\hline \multirow[t]{2}{*}{ Secondary educ. } & $-0.204^{* * *}$ & $-0.204^{* * *}$ & $-0.204^{* * *}$ \\
\hline & $(0.0411)$ & $(0.0409)$ & $(0.0411)$ \\
\hline \multirow[t]{2}{*}{ Tertiary educ. } & $-0.405^{* * *}$ & $-0.405^{* * *}$ & $-0.405^{* * *}$ \\
\hline & $(0.0691)$ & $(0.0690)$ & $(0.0692)$ \\
\hline \multirow[t]{2}{*}{ Married } & -0.0120 & -0.0119 & -0.0119 \\
\hline & $(0.0308)$ & $(0.0308)$ & $(0.0308)$ \\
\hline \multirow[t]{2}{*}{ Tenure } & $-0.0921 * * *$ & $-0.0921 * * *$ & $-0.0921 * * *$ \\
\hline & $(0.0102)$ & $(0.0102)$ & $(0.0102)$ \\
\hline \multirow[t]{2}{*}{ Public employer } & $-0.363^{*}$ & $-0.364^{*}$ & $-0.364^{*}$ \\
\hline & $(0.189)$ & $(0.189)$ & $(0.189)$ \\
\hline \multirow[t]{2}{*}{ Firm size: $20-200$} & $0.256 * * *$ & $0.256 * * *$ & $0.256 * * *$ \\
\hline & $(0.0360)$ & $(0.0360)$ & $(0.0362)$ \\
\hline \multirow[t]{2}{*}{ Firm size: $200-2000$} & $0.265^{* * *}$ & $0.265 * * *$ & $0.265^{* * *}$ \\
\hline & $(0.0450)$ & $(0.0450)$ & $(0.0450)$ \\
\hline \multirow[t]{2}{*}{ Firm size: $>2000$} & $0.247 * * *$ & $0.247 * * *$ & $0.247 * * *$ \\
\hline & $(0.0449)$ & $(0.0448)$ & $(0.0450)$ \\
\hline \multirow[t]{2}{*}{ Firm size: self-empl. } & $0.518^{*}$ & $0.517^{*}$ & $0.518^{*}$ \\
\hline & $(0.298)$ & $(0.296)$ & $(0.298)$ \\
\hline \multirow[t]{2}{*}{ Experience } & $-0.0595 * * *$ & $-0.0595 * * *$ & $-0.0594 * * *$ \\
\hline & $(0.00601)$ & $(0.00599)$ & $(0.00602)$ \\
\hline \multirow[t]{2}{*}{ Experience squared } & $0.00144 * * *$ & $0.00144 * * *$ & $0.00144 * * *$ \\
\hline & $(0.000166)$ & $(0.000166)$ & $\begin{array}{l}(0.000166) \\
\end{array}$ \\
\hline \multirow[t]{2}{*}{ Industry production } & 0.000000668 & 0.000000687 & 0.000000793 \\
\hline & $(0.00000118)$ & $(0.00000106)$ & $(0.00000111)$ \\
\hline \multirow[t]{2}{*}{$R \& D$} & 0.0000455 & 0.0000464 & 0.0000457 \\
\hline & $(0.0000409)$ & $(0.0000432)$ & $(0.0000409)$ \\
\hline \multirow[t]{2}{*}{ East } & 0.0767 & 0.0768 & 0.0767 \\
\hline & $(0.0553)$ & $(0.0554)$ & $(0.0553)$ \\
\hline \multirow[t]{2}{*}{ Constant } & 22.42 & 28.20 & 16.39 \\
\hline & (17.71) & (28.16) & (14.78) \\
\hline \# obs. & 36858 & 36858 & 36858 \\
\hline Pseudo R2 & 0.203 & 0.203 & 0.203 \\
\hline
\end{tabular}

Note: Cluster robust standard errors (clustered at two digit industry level) in parentheses; ${ }^{*} p<0.10,{ }^{* *} p<0.05$, ${ }^{* * *} p<0.01$; regressions include year dummies, industry dummies, and industry-specific time trends. 
Table 4 - Marginal effect of materials and services offshoring on wages, after FE regression, by contract type, manufacturing industries

\begin{tabular}{|c|c|c|c|c|}
\hline & & $\begin{array}{c}\text { (1) } \\
\text { Total offshoring }\end{array}$ & $\begin{array}{c}(2) \\
\text { Offshoring to } \\
\text { non-OECD }\end{array}$ & $\begin{array}{c}\text { (3) } \\
\text { Offshoring to } \\
\text { OECD }\end{array}$ \\
\hline Materials & $\begin{array}{l}\text { Permanent contract } \\
\text { Temporary contract }\end{array}$ & $\begin{array}{c}0.00269 \\
(0.00218) \\
-\mathbf{0 . 0 0 6 9 8} \\
(0.00267)\end{array}$ & $\begin{array}{c}\mathbf{0 . 0 1 1 9}^{*} \\
(0.00622) \\
-\mathbf{0 . 0 1 7 4} \\
(0.00955)\end{array}$ & $\begin{array}{c}0.00119 \\
(0.00290) \\
\mathbf{- 0 . 0 0 9 9 9 * *}^{* *} \\
(0.00440)\end{array}$ \\
\hline Services & $\begin{array}{l}\text { Permanent contract } \\
\text { Temporary contract }\end{array}$ & $\begin{array}{c}-0.00405 \\
(0.0245) \\
-0.0190 \\
(0.0343) \\
\end{array}$ & $\begin{array}{l}-0.0117 \\
(0.0292) \\
-0.0150 \\
(0.0360)\end{array}$ & $\begin{array}{c}0.0105 \\
(0.0382) \\
-0.0330 \\
(0.0460) \\
\end{array}$ \\
\hline
\end{tabular}

Note: Standard errors in parentheses; ${ }^{*} p<0.10,{ }^{* *} p<0.05,{ }^{* * *} p<0.01$

Table 5 - Marginal effect of materials and services offshoring on probability of jobloss after Probit regression, by contract type, manufacturing industries

\begin{tabular}{|c|c|c|c|c|}
\hline & & $\begin{array}{l}\text { (1) } \\
\text { Total offshoring }\end{array}$ & $\begin{array}{l}(2) \\
\text { Offshoring to } \\
\text { non-OECD }\end{array}$ & $\begin{array}{l}(3) \\
\text { Offshoring to } \\
\text { OECD }\end{array}$ \\
\hline Materials & $\begin{array}{l}\text { Permanent contract } \\
\text { Temporary contract }\end{array}$ & $\begin{array}{c}\mathbf{- 0 . 0 0 2 6 2}^{* *} \\
(0.00129) \\
\mathbf{- 0 . 0 0 5 5 3}^{*} \\
(0.00333) \\
\end{array}$ & $\begin{array}{c}-\mathbf{0 . 0 0 7 6 7} \\
(0.00384) \\
-0.0144 \\
(0.00903) \\
\end{array}$ & $\begin{array}{l}\mathbf{- 0 . 0 0 4 1 9}^{* *} \\
(0.00202) \\
\mathbf{- 0 . 0 0 9 7 1}^{*} \\
(0.00539) \\
\end{array}$ \\
\hline Services & $\begin{array}{l}\text { Permanent contract } \\
\text { Temporary contract }\end{array}$ & $\begin{array}{c}-0.0344 \\
(0.0231) \\
-\mathbf{0 . 1 1 0} \\
(0.0610)\end{array}$ & $\begin{array}{c}-0.00486 \\
(0.0134) \\
-0.0636 \\
(0.0387)\end{array}$ & $\begin{array}{c}-0.0322 \\
(0.0248) \\
-0.104 \\
(0.0692)\end{array}$ \\
\hline
\end{tabular}

Note: Standard errors in parentheses; ${ }^{*} p<0.10,{ }^{* *} p<0.05,{ }^{* * *} p<0.01$ 
Table 6 - Marginal effect of materials and services offshoring on wages, after FE regression, by contract type, services industries

\begin{tabular}{lcccc}
\hline & & $(1)$ & $\begin{array}{c}(2) \\
(3) \\
\text { Offshoring to } \\
\text { non-OECD }\end{array}$ & $\begin{array}{c}\text { Offshoring to } \\
\text { OECD }\end{array}$ \\
\hline Materials & Permanent contract & Total offshoring & 0.0281 & 0.00886 \\
& Temporary contract & $(0.00544)$ & $(0.0207)$ & $(0.00647)$ \\
& & 0.00234 & -0.0117 & 0.00321 \\
& Permanent contract & $(0.00904)$ & $(0.0366)$ & $(0.0114)$ \\
\hline Services & Temporary contract & $(0.0118$ & 0.0212 & 0.0107 \\
& & $-0.00818)$ & $(0.0233)$ & $(0.0149)$ \\
& & $(0.0185)$ & -0.0810 & $(0.0107$ \\
\end{tabular}

Note: Standard errors in parentheses; ${ }^{*} p<0.10,{ }^{* *} p<0.05,{ }^{* * *} p<0.01$

Table 7 - Marginal effect of materials and services offshoring on probability of jobloss after Probit regression, by contract type, services industries

\begin{tabular}{|c|c|c|c|c|}
\hline & & $\begin{array}{l}\text { (1) } \\
\text { Total offshoring } \\
\end{array}$ & $\begin{array}{c}\text { (2) } \\
\text { Offshoring to } \\
\text { non-OECD }\end{array}$ & $\begin{array}{c}\text { (3) } \\
\text { Offshoring to } \\
\text { OECD }\end{array}$ \\
\hline \multirow[t]{2}{*}{ Materials } & Permanent contract & $\begin{array}{c}0.00163 \\
(0.00385)\end{array}$ & $\begin{array}{c}0.0136 \\
(0.0170)\end{array}$ & $\begin{array}{l}0.000549 \\
(0.00378)\end{array}$ \\
\hline & Temporary contract & $\begin{array}{l}-0.000434 \\
(0.00828)\end{array}$ & $\begin{array}{c}0.0194 \\
(0.0364)\end{array}$ & $\begin{array}{l}-0.00383 \\
(0.00771)\end{array}$ \\
\hline \multirow[t]{2}{*}{ Services } & Permanent contract & $\begin{array}{l}-0.00569 \\
(0.00697)\end{array}$ & $\begin{array}{c}0.0122 \\
(0.00886)\end{array}$ & $\begin{array}{l}\mathbf{- 0 . 0 1 0 4}^{*} \\
(0.00623)\end{array}$ \\
\hline & Temporary contract & $\begin{array}{l}-0.0136 \\
(0.0132)\end{array}$ & $\begin{array}{c}0.0211 \\
(0.0141)\end{array}$ & $\begin{array}{l}\mathbf{- 0 . 0 2 3 8}^{\text {*** }} \\
(0.0117)\end{array}$ \\
\hline
\end{tabular}

Note: Standard errors in parentheses; ${ }^{*} p<0.10,{ }^{* *} p<0.05,{ }^{* * *} p<0.01$ 